\title{
DESIGNING LEARNING ROTATION USING THE CONTEXT OF BAMBOO WOVEN MOTIF
}

\author{
${ }^{1}$ Maryati, ${ }^{2}$ Rully Charitas Indra Prahmana \\ ${ }^{1}$ SMP Muhammadiyah 1 Tepus, Pule Ireng, Tepus, Gunung Kidul, Yogyakarta, Indonesia \\ ${ }^{2}$ Universitas Ahmad Dahlan, Jl. Pramuka 42, Pandeyan, Umbulharjo, Yogyakarta, Indonesia \\ e-mail: rully.indra@mpmat.uad.ac.id
}

\begin{abstract}
An essential part of learning transformation geometry is rotation. Before learning more about other parts of the transformation geometry topic, such as translation, dilation, and reflection, firstly, students are required to understand well about rotation. However, several students have not been able to understand this subject properly due to the stages of learning in the rotation has not been appropriately arranged. Thus, this study aims to design a student learning trajectory in learning rotation, which develop from informal to formal level through the Indonesian Realistic Mathematics Education (IRME) approach. Furthermore, researchers used a design research method divided into three stages, namely preliminary design, design experiments, and retrospective analysis. This study describes how the bamboo woven motif contributes significantly to 31 ninth-grade students understanding the rotation concept. As a result, the woven bamboo motif's context can stimulate students' understanding of rotation. It is proven based on the strategies and models of students during their learning process which contributes to their fundamental knowledge of rotation.
\end{abstract}

Keywords: Bamboo woven motif, Indonesian Realistic Mathematics Education, Rotation, Design Research

\begin{abstract}
Abstrak
Salah satu bagian penting dari pembelajaran transformasi geometri adalah pembelajaran rotasi. Sebelum mempelajari lebih jauh terkait bagian-bagian lain dari topik transformasi geometri, seperti translasi, dilatasi, dan refleksi, siswa dituntut untuk memahami dengan baik materi rotasi terlebih dahulu. Namun, banyak siswa belum mampu memahami materi ini dengan baik yang disebabkan oleh tahapan-tahapan dalam pembelajaran pada materi rotasi belum tersusun dengan baik. Sehingga, penelitian ini bertujuan untuk menghasilkan sebuah lintasan belajar siswa dalam pembelajaran rotasi, yang berkembang dari bentuk informal ke bentuk formal melalui pendekatan Pendidikan Matematika Realistik Indonesia (PMRI). Selanjutnya, peneliti menggunakan penelitian desain (design research) yang dibagi menjadi 3 tahapan, yaitu desain pendahuluan, percobaan desain, dan analisis retrospektif. Penelitian ini mendeskripsikan bagaimana motif Anyaman Bambu memberikan kontribusi nyata untuk 31 siswa kelas IX dalam memahami konsep rotasi. Hasilnya, konteks motif anyaman bambu dapat merangsang pemahaman siswa tentang rotasi. Ini terbukti berdasarkan pada strategi dan model siswa selama proses pembelajaran mereka yang berkontribusi pada pengetahuan dasar mereka tentang rotasi.
\end{abstract}

Kata Kunci: Motif anyaman bambu, Pendidikan Matematika Realistik Indonesia, Rotasi, Design Research

\section{INTRODUCTION}

Rotation is a circular motion that moves points by rotating these points $\theta$ to a central point of rotation (Maryati \& Prahmana, 2019). Furthermore, Risdiyanti \& Prahmana (2018) show that learning about transformation geometry, especially rotation, can be used to design learning using the local contexts such as culture or other things that are easily found in students' daily activities. On the other hand, students can understand mathematical concepts easily, fun, close to daily activities, and affordable to students' imagination (Zulkardi, 2013; Adams \& Cook, 2017; Clarke \& Roche, 2018). Thus, it would be made it easier for students to be able to solve the problems encountered in students' daily life. 
The Program for International Student Assessment (PISA) results analyzed by Stacey (2011) shows that Indonesian students still have difficulty in formulating problems in daily life into mathematical models. One example is interpreting the context of real situations into mathematical models, understanding mathematical structures, including order, relationships, and patterns (Edo, Hartono, \& Putri, 2013; Revina \& Leung, 2019). One contributing factor is the process of learning mathematics, which tends to use practical formulas and has not connected mathematical concepts with students' daily activities (Naidoo, 2012; Arisetyawan, Suryadi, Herman, \& Rahmat, 2014). Therefore, meaningful learning activities are needed so that students can master the concepts and traits of rotation easily and fun.

One of the learning approaches that can connect the learning subject with daily life is the Indonesian Realistic Mathematics Education (IRME) (Sembiring, Hadi, \& Dolk, 2008). The IRME is an adaptation of Realistic Mathematics Education (RME) and has been developed in accordance with the context, cultural values, or local wisdom in Indonesia (Lestariningsih, Putri, \& Darmawijoyo, 2015). The IRME places more emphasis on the processes that occur during the learning process so that they are not only concerned with the final results (Sembiring et al., 2008). Thus, IRME could be used as a solution in a learning approach that wants to connect a mathematical material with daily student activities.

IRME is one of the learning approaches that will lead students to understand mathematical concepts by constructing themselves through prior knowledge related to daily life (Revina \& Leung, 2019; Risdiyanti \& Prahmana, 2020). Furthermore, by discovering the concept by themselves, the students' learning process will become more meaningful. In addition, one of the developments in IRME was carried out with research aimed at improving classroom learning practices through an interactive analysis of hypothetical learning trajectory of what would happen in the classroom and its implementation, the research was design research (Cobb \& Gravemeijer, 2006).

As an innovation in learning mathematics and as an implementation of the 2013 curriculum which is oriented to the relationship of mathematics to the conditions of reality and culture of students, researchers designing learning rotation using the context of the woven bamboo motif through the IRME approach. This context was chosen because it is close to students and easily found in students' daily lives. Through this design, it is expected to be an innovation in learning mathematics that can facilitate students in understanding the concept of rotation and be able to solve everyday problems related to the concept and further concept in transformation geometry, such as translation, dilatation, and reflection. 


\section{RESEARCH METHOD}

This study's research method is design research, which is an appropriate way to answer research questions and achieve research objectives, starting with a preliminary design, design experiments, and retrospective analysis (Cobb \& Gravemeijer, 2006; Prahmana, 2017). In the preliminary design, the researcher implements the initial idea of using the context of the bamboo woven motif in learning rotation by studying the literature. After reviewing the previous research, curriculum in Indonesia, and mathematics textbook, the researcher does observations at SMP N 1 Tepus to see the students' initial abilities used as the basis for designing the prototype rotation learning trajectory. In the design experiments phase, researchers tested the learning trajectory that has been developed at the preliminary design stage. Lastly, after the design experiments stage, data obtained from learning activities in class are analyzed. The results are used to plan activities or to develop designs for subsequent learning activities. At this stage, data analysis conducted in this study was to compare the observations during the learning process with the Hypothetical Learning Trajectory that had been designed at the preliminary design stage.

The subjects in this study were IXA grade students of SMP Negeri 1 Tepus consisting of 31 students. Data collection techniques used in this study include video recording, documentation, written data, and observation. In this research, the design of learning rotation utilizing the context of the Bamboo woven motif is compared with actual student learning. Therefore, to what extent the design process and implementation of this rotation learning design would be explored in this research.

\section{RESULTS AND DISCUSSION}

The results obtained in this study in the form of learning trajectories in learning rotation using the context of the bamboo woven motif through the PMRI approach. The following is an explanation of the learning process of rotation material in class IXA

\section{The Early Learning Phase}

Learning begins with giving assignments in groups (4-5 people per group), namely working on the Student Worksheet (SW) entitled "Activity 2". This activity aims to bring up the language or understanding of students about the concept of rotation. Describing the activities in this learning process begins with the teacher instructing all students to gather with their respective groups. Next, the teacher gives assignments to each group to work on the SW 
entitle "Activity 2" about the concept of rotation. Activities in the SW start from preparing the Anyaman and ornaments, as shown in Figure 1.

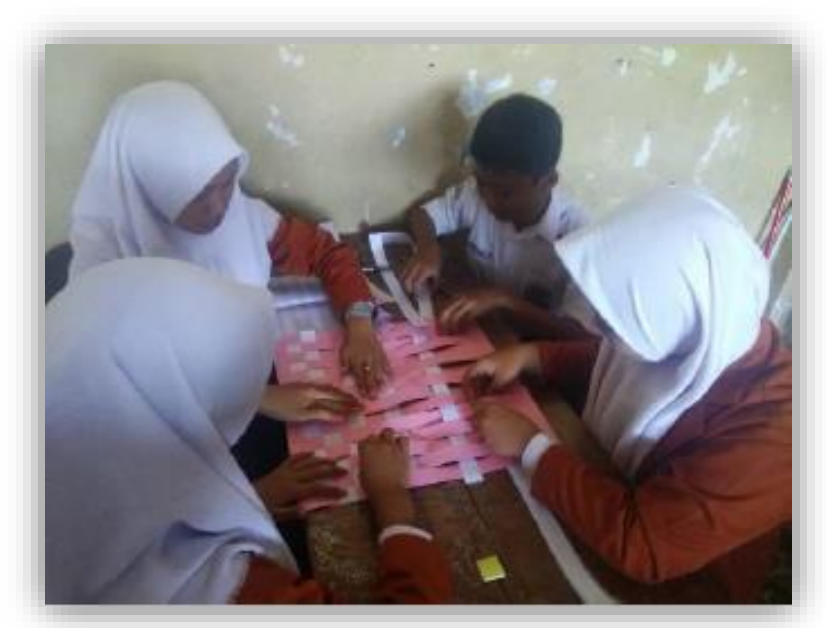

Figure 1. Students make the ornaments using manila paper

\section{The Informal Phase}

At this stage, students do activities based on the steps or instructions on the SW entitle "Activity 2" which starts from preparing the woven and ornamentation. After all, students are ready with their weaving and ornaments, and the teacher instructs each group to record the initial coordinates and the final coordinates after they are rotated according to the instructions in the worksheet. In Figure 2, students are seen rotating the ornaments according to the instructions in SW "Activity 2" to get a starting point and endpoint.

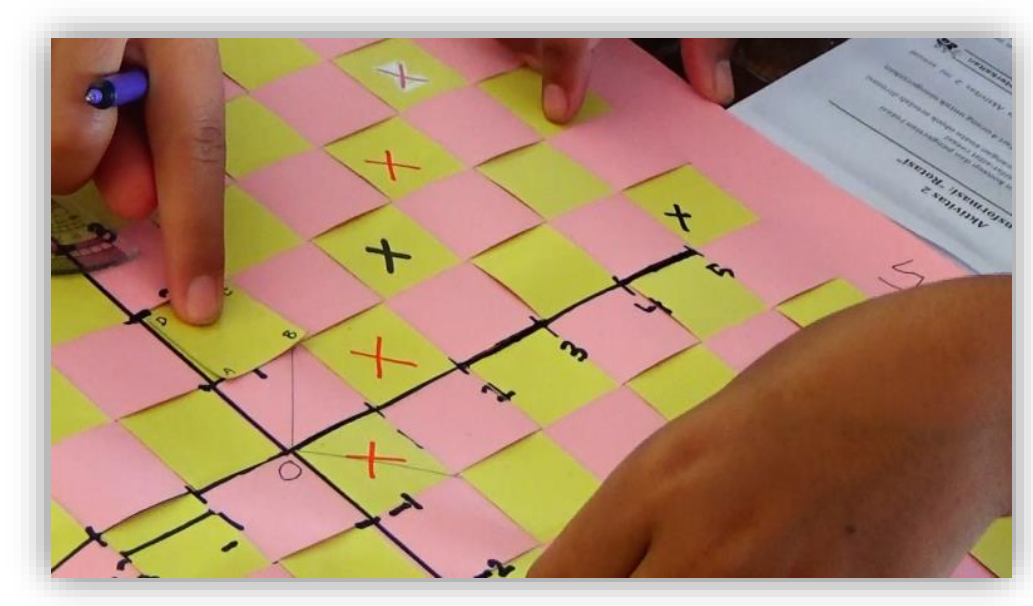

Figure 2. Students rotate the ornaments and calculate the coordinates (Informal)

\section{The Phase of Model Of}

At this stage, students write the coordinate points that have been obtained at an informal stage in a table, as shown in Figure 3. 


\begin{tabular}{|c|c|c|c|c|c|c|}
\hline \multirow{2}{*}{$\begin{array}{l}\text { Soal } \\
\text { Nomor }\end{array}$} & \multirow{2}{*}{$\begin{array}{l}\text { Nama } \\
\text { Titik }\end{array}$} & \multirow{2}{*}{$\begin{array}{l}\text { Posisi } \\
\text { Awal } \\
\text { Titik }\end{array}$} & \multicolumn{3}{|c|}{ Perputaran } & \multirow{2}{*}{$\begin{array}{l}\text { Posisi } \\
\text { Akhir } \\
\text { Titik }\end{array}$} \\
\hline & & & Arah & $\begin{array}{l}\text { Besar } \\
\text { Sudut }\end{array}$ & $\begin{array}{l}\text { Titik } \\
\text { Pusat }\end{array}$ & \\
\hline \multirow[t]{4}{*}{2} & A & $(1, \ldots, 1)$. & Kanan & $90^{\circ}$ & $(0,0)$ & $(1,-1)$ \\
\hline & $B$ & $(2,1)$. & Kanan & $90^{\circ}$ & $(0,0)$ & $(1,-,-2)$ \\
\hline & C & $(2,2)$ & Kanan & $90^{\circ}$ & $(0,0)$ & $(2,2)$ \\
\hline & $D$ & $(1,2)$ & Kanan & $90^{\circ}$ & $(0,0)$. & $(2,-1)$ \\
\hline \multirow[t]{4}{*}{3} & A & $(1, \ldots)$ & Kanan & $180^{\circ}$ & $(0,0)$ & $(-1,-1)$ \\
\hline & $B$ & $(2,1)$ & Karian & $180^{\circ}$ & $(0,0)$ & $(-2,-1)$ \\
\hline & c & $(2,2)$ & Kanan & $180^{\circ}$ & $(0,0)$ & $(-7,-2)$ \\
\hline & $D$ & $(1,2)$ & Kanan & $180^{\circ}$ & $(0,0)$ & $(-1, \ldots-2)$ \\
\hline \multirow[t]{3}{*}{4} & A & $(1,1)$. & Kanan & $270^{\circ}$ & $(0,0)$ & $(-1,1)$ \\
\hline & $B$ & $(2, \ldots)$ & Kanan & $270^{\circ}$ & $(0,0)$ & $(-1,2)$ \\
\hline & C & $(2,2)$ & Kanan & $270^{\circ}$ & $(0,0)$ & $(-2,2)$ \\
\hline
\end{tabular}

\begin{tabular}{|c|c|c|c|c|c|c|}
\hline \multirow[b]{2}{*}{$\begin{array}{l}\text { Soal } \\
\text { Nomor }\end{array}$} & \multirow[b]{2}{*}{$\begin{array}{l}\text { Nama } \\
\text { Titik }\end{array}$} & \multirow[b]{2}{*}{$\begin{array}{l}\text { Posisi } \\
\text { Awal } \\
\text { Titik }\end{array}$} & \multicolumn{3}{|c|}{ Perputaran } & \multirow[b]{2}{*}{\begin{tabular}{|c} 
Posisi \\
Akhir \\
Titik \\
\end{tabular}} \\
\hline & & & Arah & $\begin{array}{l}\text { Besar } \\
\text { Sudut }\end{array}$ & $\begin{array}{l}\text { Titik } \\
\text { Pusat } \\
\end{array}$ & \\
\hline & D & $(1,2)$ & Kanan & $270^{\circ}$ & $(0,0)$ & $(-2,1)$ \\
\hline \multirow[t]{4}{*}{5} & A & $(1,1)$. & Kiri & $90^{\circ}$ & $(0,0)$ & $(-1,1,1)$ \\
\hline & B & $(2,1)$ & Kiri & $90^{\circ}$ & $(0,0)$ & $(\pi\}, 2)$ \\
\hline & c & $(2,2)$ & Kiri & $90^{\circ}$ & $(0,0)$ & $(-2,2)$ \\
\hline & D & $(1,2)$ & Kiri & $90^{\circ}$ & $(c, 0)$ & $(-2,1)$ \\
\hline \multirow[t]{4}{*}{6} & A & $(1.1)$. & Kiri & $180^{\circ}$ & $(0,0)$ & $(-1,-1)$ \\
\hline & B & $(2,1)$ & Kiri & $180^{\circ}$ & $(0,0)$ & $(-2,-1)$ \\
\hline & c & $(2,2)$ & Kiri & $180^{\circ}$ & $(0.0)$ & $(-2,-2)$ \\
\hline & D & $(1,2)$ & $K_{\text {ri }}$ & $180^{\circ}$ & $(0,0)$ & $(-.1,-2)$ \\
\hline & A & $(1 ., 1)$. & Kiri & $270^{\circ}$ & $(0,0)$ & $(1,-1)$ \\
\hline & B & $(2,4)$ & Kiri & $270^{\circ}$ & $(0,0)$ & $(1,-2)$ \\
\hline & c & $(2,2)$ & Kiri & $270^{\circ}$ & $(0,0)$ & $(2,-2)$ \\
\hline & D & $(1,2)$ & Kiri & $270^{\circ}$ & $(0,0)$ & $(2,-3)$ \\
\hline
\end{tabular}

Figure 3. Student work results record the starting point and endpoint of the rotation results in a table (Model of)

\section{The Phase of Model For}

At this stage, students analyze the change from a starting point to an endpoint and make interpretations related to the concept of rotation with their own language, as shown in Figure 4.

Cermatilah tabel yang telah kalian lengkapi!

1. Apa yang kamu dapatkan mengenai hubungan antara posisi awal titik dengan posisi akhir titik setelah diputar?

- Jika diputar ke kanan Sebesar go

maka fitik akhirnya $(y-x)$

- Jika diputar Ke Kanan Seberar.... $180^{\circ}$

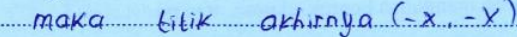

- Jika diputar Ke kanan Sebesar $270^{\circ}$

maka titik akhirnya $(-y, x)$

- Jika diputar ke kan Kir sebesar

- go maka titik akhirnya (-x x $)$

- Itka diputar ke kiri sebesar $180^{\circ}$

maka titik akhirnya

- Jika dipatar He Kir. \& Sebesor

$270^{\circ}$ maka titik akhirnya

Figure 4. Students write the results of their interpretation related to the concept of rotation in the worksheet (Model for) 


\section{Formal Phase}

At this stage, students make mathematical modeling in the form of a rotation formula according to their respective understanding. The results of students' mathematical modeling can be seen in Figure 5.

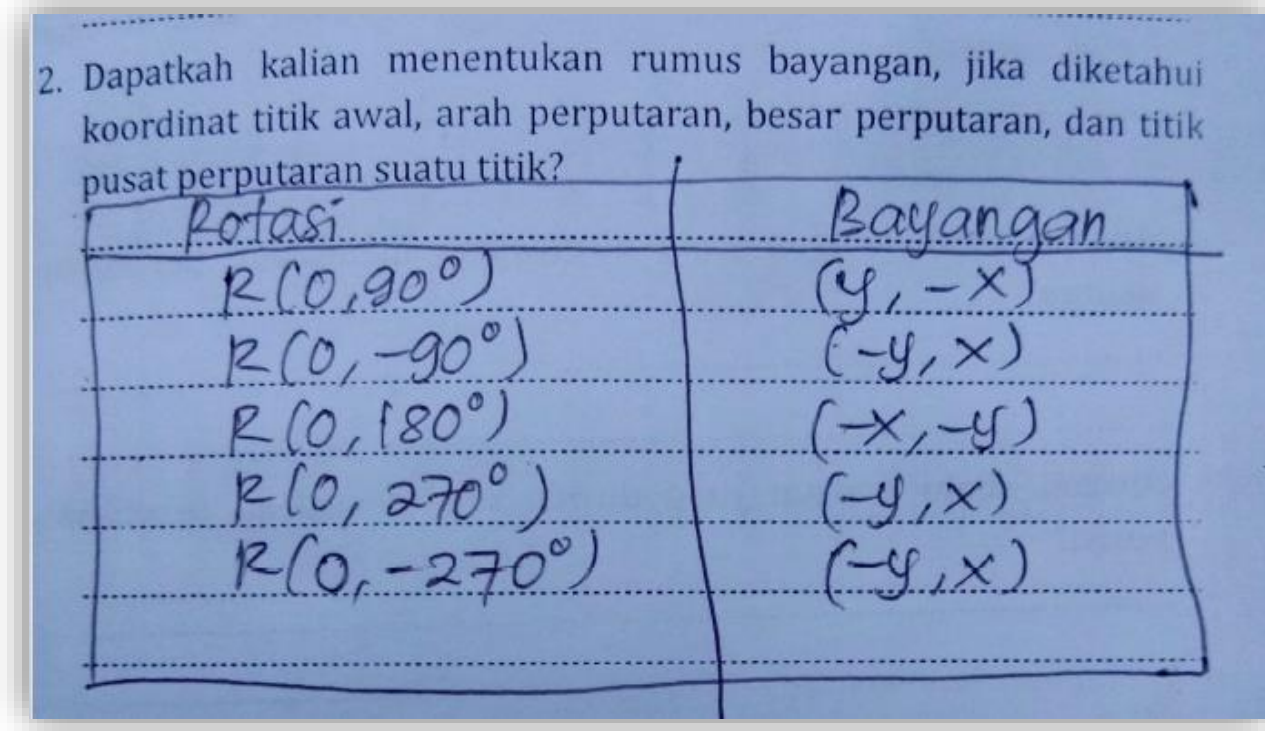

Figure 5. Student mathematical modeling results related to the rotation formula (formal)

A class discussion is needed to classify the results of student answers listed in the worksheet. Therefore, the teacher invites each group to present their work. Students are seen presenting the concept of rotation, as shown in Figure 6.

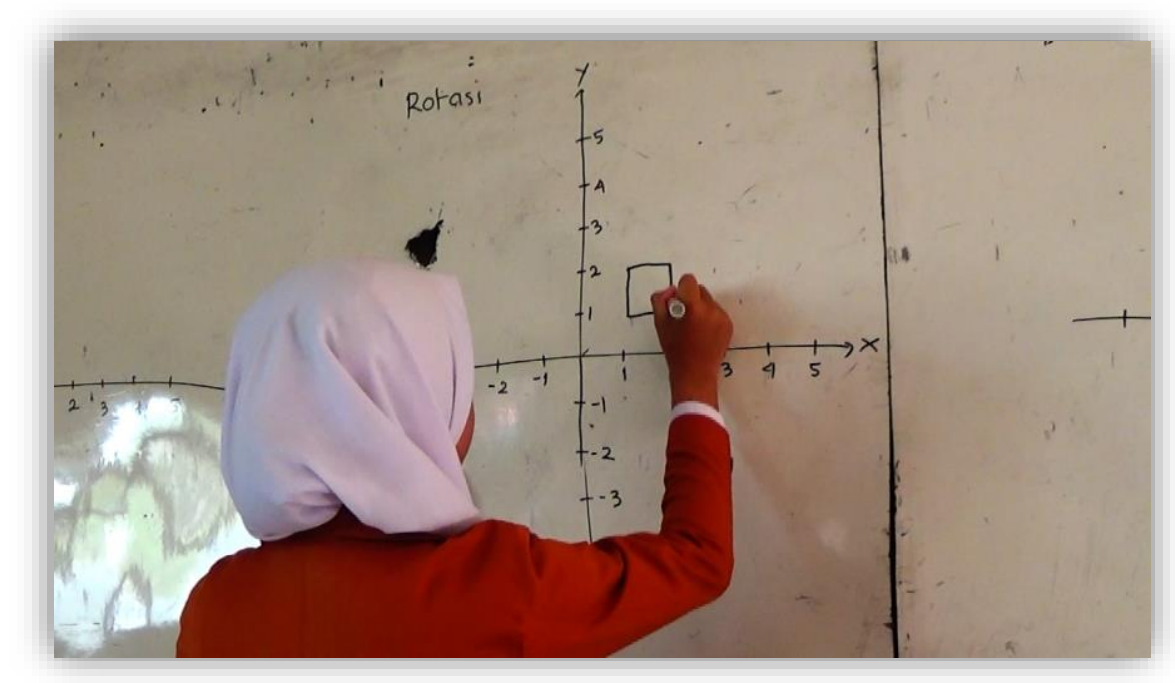

Figure 6. Students present about rotation

During the discussion process, it seemed that the participants in the discussion were very enthusiastic about expressing their opinions and ideas on the work done by each group's 
worksheet. It is caused by the position of the ornamental starting point that is different from each discussion group so that the position of the ornamental endpoint will also be different. Furthermore, the teacher guides students to have five common perceptions of the concept of rotation. Firstly, if the starting point is rotated 90 degrees to the right with a center point $(0.0)$, then the endpoint will be the opposite, but the back is negative. Secondly, if the starting point is rotated 90 degrees to the left with the center point $(0,0)$, then the endpoint will be the opposite, but the front is negative. Thirdly, if the starting point is rotated 180 degrees to the right and to the left with the center point $(0,0)$, then the endpoint will be the same that is to be all negative. Fourthly, if the starting point is rotated as far as 270 degrees to the right with the center point $(0,0)$, then the endpoint will be the opposite, but the front negative. Lastly, if the starting point is rotated 270 degrees to the left with the center point $(0,0)$, then the endpoint will be the opposite, but the back is negative.

In addition, some researchers have also made mathematics learning design using IRME approaches and cultural contexts, such as learning number pattern using "Barathayudha" war stories (Risdiyanti \& Prahmana, 2020), rotational learning designs using kawung batik motifs (Risdiyanti \& Prahmana, 2018), the design of transformation learning using Sidoarjo written batik motifs (Lestariningsih \& Mulyono, 2017), and learning number operation using traditional Indonesian game "Tepuk Bergambar" (Prahmana, Zulkardi, \& Hartono, 2012). Therefore, the role taken from the results of this study is to enrich the study of mathematics learning design that is a rotational learning design using the context of the woven bamboo motif.

\section{CONCLUSION}

Learning trajectories that can support the concept of rotation from informal to formal level include the activity of recording the starting and ending points of ornamentation on the webbing field, analyzing and interpreting the change of the starting point into an endpoint using their own language, and writing the rotation formula. The context of the woven bamboo motif can stimulate students' concept of rotation.

\section{REFERENCES}

Adams, K. D., \& Cook, A. M. (2017). Performing mathematics activities with non-standard units of measurement using robots controlled via speech-generating devices: Three case studies. Disability and Rehabilitation: Assistive Technology, 12(5), 491-503.

Arisetyawan, A., Suryadi, D., Herman, T., \& Rahmat, C. (2014). Study of Ethnomathematics: A lesson from the Baduy Culture. International Journal of Education and Research, 
2(10), 681-688.

Clarke, D., \& Roche, A. (2018). Using contextualized tasks to engage students in meaningful and worthwhile mathematics learning. The Journal of Mathematical Behavior, 51, 95108.

Cobb, P., \& Gravemeijer, K. (2006). Educational Design Research. London: Routledge.

Edo, S. I., Hartono, Y., \& Putri, R. I. I. (2013). Investigating secondary school students' difficulties in modeling problems PISA-model level 5 and 6. Journal on Mathematics Education, 4(1), 41-58.

Lestariningsih, \& Mulyono, I. (2017). Desain pembelajaran transformasi menggunakan motif batik tulis Sidoarjo. Jurnal Edukasi, 3(1), 83-98.

Lestariningsih, Putri, R. I. I., \& Darmawijoyo. (2015). The legend of Kemaro island for supporting students in learning average. Journal on Mathematics Education, 3(2), 165 174.

Maryati, \& Prahmana, R. C. I. (2019). Ethnomathematics: Exploration of the Muntuk community. International Journal of Scientific \& Technology Research, 8(06), 47-49.

Naidoo, J. (2012). Teacher reflection: The use of visual tools in mathematics classrooms. Pythagoras, 33(1), 1-9.

Prahmana, R. C. I. (2017). Design Research (Teori dan Implementasinya: Suatu Pengantar). Jakarta: Rajawali Pers.

Prahmana, R. C. I., Zulkardi, \& Hartono, Y. (2012). Learning multiplication using Indonesian traditional game in third grade. Journal on Mathematics Education, 3(2), 115-132.

Revina, S., \& Leung, F. K. S. (2019). How the same flowers grow in different Soils? The implementation of realistic mathematics education in Utrecht and Jakarta classrooms. International Journal of Science and Mathematics Education, 17(3), 565589.

Risdiyanti, I., \& Prahmana, R. C. I. (2018). Desain hypothetical learning trajectory dalam pembelajaran rotasi menggunakan motif batik Kawung. Prima: Jurnal Pendidikan Matematika, 2(1), 19-32.

Risdiyanti, I., \& Prahmana, R. C. I. (2020). The learning trajectory of number pattern learning using "Barathayudha" war stories and uno stacko. Journal on Mathematics Education, 11(1), 157-166.

Sembiring, R. K., Hadi, S., \& Dolk, M. (2008). Reforming mathematics learning in Indonesian classrooms through RME. ZDM - International Journal on Mathematics Education, 
40(6), 927-939.

Stacey, K. (2011). The PISA view of mathematical literacy in Indonesia. Journal on Mathematics Education, 2(2), 95-126.

Zulkardi. (2013). Designing joyful and meaningful new school mathematics using Indonesian realistic mathematics education. Southeast Asian Mathematics Education Journal, 3(1), $17-25$. 